\title{
Gender Relations and Reproductive Decision Making In Honduras
}

CONTEXT: Gender differences influence decision making about reproductive health. Most information on reproductive health decision making in Latin America has come from women's reports of men's involvement.

METHODS: Data were collected in Honduras in 2001 through two national surveys that used independent samples of men aged 15-59 years and women aged 15-49. Bivariate and multivariate analyses were used to identify factors associated with male-centered decision-making attitudes and behaviors regarding family size and family planning use.

RESULTS: Overall, $25 \%$ of women and $28 \%$ of men said that men alone should be responsible for at least one of these reproductive decisions, and $27 \%$ of women and $21 \%$ of men said that the man in their household made one or both decisions. For women, having no children and being in a consensual union were each associated with holding malecentered decision-making attitudes; having less than a secondary education, being of medium or low socioeconomic status and living in a rural area were each associated with male-centered decision making. Among men, having less than secondary education and being in a consensual union were each associated with male-centered decisionmaking attitudes and behavior. Women who had ever used or were currently using modern methods were significantly less likely to hold attitudes supporting male-centered decision-making than were those who relied on traditional methods and those who had never used a modern method.

CONCLUSIONS: Programs should recognize power imbalances between genders that affect women's ability to meet their stated fertility desires. In rural areas, programs should target men, encouraging them to communicate with their wives on reproductive decisions.

International Family Planning Perspectives, 2005, 31(3):131-139
By llene S. Speizer, Lisa Whittle and Marion Carter

When the work was performed, Ilene S. Speizer was a consultant, Lisa Whittle was an ORISE fellow and Marion Carter was an epidemic intelligence service officer, all at the Division of Reproductive Health, Centers for Disease Control and Prevention, Atlanta, GA, USA.
The international reproductive health community has acknowledged the importance of addressing gender disparities in sexual relations and reproductive health decision making as fundamental to improving the reproductive health and rights of both women and men. Gender-based power inequalities can contribute to poor health outcomesfor example, by hindering communication between partners about reproductive health decisions, by constraining women's access to reproductive health services, by preventing women's and men's attainment of sexual health and pleasure, and by increasing their risk of contracting HIV infection and other STIs. ${ }^{1}$

Gender inequality in reproductive decision making is a key element of the social context of reproductive health. Research shows that couples often disagree about the desirability of pregnancy and the use of contraceptives. ${ }^{2}$ When this discordance occurs in a situation of male authority, men's opinions about these issues may overrule women's, even though the women often must implement the decisions made on these matters. In some cases, husbands fear that if they approve of family planning and allow their wife to use it, they will lose their role as head of the family, their wife may be unfaithful or they may lose face in their community. ${ }^{3}$ Even when men approve of family planning in theory, they may disapprove of their partners' practicing con- traception and may be unwilling to use male condoms. ${ }^{4}$ As a result, women may sacrifice their own wishes to those of their partners-or their perception of their partners' wishes. ${ }^{5}$ Alternatively, women may practice contraception covertly, potentially exposing themselves to financial vulnerability or emotional or physical violence if discovered. ${ }^{6}$ Conversely, women who have some decision-making power and autonomy often are better able than other women to meet their reproductive health goals. ${ }^{7}$

The bargaining power between men and women in Latin America on these and other issues is undergoing transformation, in tandem with rapid social, economic and political changes in the region. ${ }^{8}$ In many parts of postcolonial Latin America, men of varying classes and ethnicities have historically acted as family providers and patriarchs, assuming responsibility for their families' reproductive health decisions and controlling their wives' access to reproductive health services. ${ }^{9}$ Over the past few decades, however, civil wars; growing feminist movements; high rates of unemployment, inflation and migration; and increased global media access have spurred major changes. Central American women are now staying in school longer, migrating to urban areas, participating in the labor force, marrying later, using contraceptives and having smaller families. ${ }^{10}$ For men, similar changes-including increased migration to urban 
areas, later marriage, and greater acceptance and use of contraceptives-are taking place.

The effects of these changes on gender-related decision making-and reproductive health decision making in particular-are unclear and difficult to untangle. In this report, we aim not to explain these effects but rather to characterize the social and household contexts of reproductive health decision making in Honduras, one of many countries undergoing rapid social changes.

In Honduras, a small country with a population of about 6.7 million, the total fertility rate decreased from 7.4 lifetime births per woman in 1971 to 4.4 in 2001. ${ }^{11}$ Women's increased participation in the labor force and higher educational attainment have been associated with increased contraceptive use. ${ }^{12}$ The proportion of married women aged 15-44 years using any method rose from 50\% in 1996 to $62 \%$ in 2001; most of this increase was due to greater use of the injectable. ${ }^{13}$ In 2001, the most commonly used modern methods were female sterilization (29\%), the pill (17\%), the injectable (16\%) and the IUD (16\%). The condom-a partner-dependent method-was used by only $5 \%$ of married women.

Our analysis is based on information collected from women and men who are married (though not to each other). It thus offers a unique opportunity to compare men's and women's reports on who should make reproductive health decisions (attitudes) with reports on who actually makes those decisions in the respondent's own household. We examined attitudes and reported behaviors regarding decision making on two reproductive health issues-family size and contraceptive use.

\section{METHODS}

Data Sources

Data for this research came from two nationally representative surveys conducted in 2001 by the Honduran Association of Family Planning (ASHONPLAFA) with technical assistance from the U.S. Centers for Disease Control and Prevention: the Epidemiology and Family Health National Survey (ENESF-2001), which involved 8,362 female respondents aged $15-49$ (weighted $N=11,990$ ), and the National Survey of Men's Health (ENSM-2001), which collected data from 3,247 men aged 15-59 (weighted $\mathrm{N}=4,968$ ).

The surveys used multistage sampling designs in which the primary sampling units represented census segments. For the survey of men, 200 primary sampling units were selected; for the survey of women, 400 different primary sampling units were selected. For the survey of women, the probability of selection as a primary sampling unit was proportional to population size. For the survey of men, primary sampling units were selected with probability proportional to size after stratification by residential location (Tegucigalpa, San Pedro Sula, other urban areas, and rural areas). In both surveys, 30 households were selected in each primary sampling unit; every household in a given unit had an equal probability of selection. Finally, the data were
TABLE 1. Percentage distribution of Honduran women and men in union, by selected characteristics, Epidemiology and Family Health National Survey and National Survey of Men's Health, 2001

Characteristic

Women Men $(\mathrm{N}=7,158) \quad(\mathrm{N}=2,686)$

Residence

Tegucigalpa

San Pedro Sula

11.8

Other urban

7.6

Other

$8.4 \quad 7.6$

Rural

$\begin{array}{ll}24.6 & 24.8 \\ 54.0 & 55.8\end{array}$

Age (yrs.) ${ }^{* * *}$

15-24

$29.1 \quad 14.0$

25-29

30-34

35-39

$\geq 40$

19.0

16.9

15.1

20.0

No. of living children***

$1-2$

3-4

$\geq 5$

15.9

16.4

14.8

38.9

Educational level**

None

Primary

Secondary

>secondary

$\begin{array}{ll}7.0 & 7.2\end{array}$

$37.4 \quad 31.1$

$30.7 \quad 27.4$

$24.9 \quad 34.3$

Socioeconomic level

Low

Medium

High

$11.9 \quad 16.1$

$64.2 \quad 63.1$

$19.6 \quad 15.1$

$\begin{array}{ll}4.3 & 5.7\end{array}$

\section{Religion***}

Catholic

Protestant

Other/none

$38.2 \quad 43.6$

$37.6 \quad 37.2$

$24.2 \quad 19.2$

Type of union

Marriage

Consensual union

$51.9 \quad 54.0$

$34.8 \quad 24.7$

$13.3 \quad 21.3$

Partner's relative education*

Lower

Same

Higher

Don't know

$42.2 \quad 43.7$

$57.8 \quad 56.3$

Ever/current contraceptive use

Never used a modern method

Ever used a modern method but not now

Uses modern reversible method

Uses sterilization

Uses traditional method

$18.1 \quad 19.9$

$62.4 \quad 61.3$

$16.2 \quad 17.0$

$3.4 \quad 1.8$

${ }^{*} \mathrm{p} \leq .05 .{ }^{* *} \mathrm{p} \leq .01 .{ }^{* * *} \mathrm{p} \leq .001$. Notes: All values are adjusted for weighting and clustered survey design; the unweighted sample comprised 5,741 women and 2,134 men. Levels of significance were calculated by using an adjusted Pearson Wald $F$-test.

weighted by the number of eligible respondents in the household. In the sample of men, weights were also adjusted by age and marital status to make the sample comparable to the sample for the 1996 ENSM, which had a higher participation rate than the 2001 sample.

\section{Measures}

For this study, we analyzed responses to survey items assessing respondents' attitudes on whether men or women should generally make decisions regarding family size and 
family planning use, and on who actually does make those decisions in the respondents' households. Because only respondents living with a partner were asked about decision making in their household, the study sample was limited to the 7,158 women (unweighted $N=5,741$ ) and 2,686 men (unweighted $\mathrm{N}=2,134$ ) who were married or in consensual unions at the time of the survey. ${ }^{*}$ Because the male and female samples were independent, we could not examine couples' decision making.

The survey questions on specific attitudes about who should make decisions were "Who do you think should decide the number of children that a couple should have?" and "Who should decide if the couple should use any family planning method?" To assess decision making in the respondent's household, the survey asked, "Who decides about the following in your household: use of contraceptives and how many children the couple should have?" Response options for both types of questions were husband, wife, ${ }^{\dagger}$ both, other, not applicable. We categorized the decision-making attitudes and behaviors as male-centered, meaning the husband alone made the decisions, or not male-centered, meaning the wife alone made the decisions or the husband and the wife made the decisions together. We focused on male-centered attitudes and practices because, in comparison with joint or woman-centered decision making, they are easier to interpret and are arguably of greater interest to people addressing gender disparities in reproductive health.

For the purposes of this study, our interest in male-centered decision making arises from its potential consequences for family life, since male-centered decision making may favor men's interests over women's. The data for this project were cross-sectional and thus cannot be used to establish the consequences of decision-making patterns; however, they can identify associations between decision-making attitudes and practices and provide evidence about the practical consequences of male-centered decision making. To that end, we examined the relationship between a respondent's opinion that husbands alone should make family planning decisions and the respondent's contraceptive use. Likewise, we examined the relationship between a respondent's report that the husband alone did make household family planning decisions and the respondent's family planning method use.

The variable for family planning use was created on the basis of reports about current use of family planning (defined as use in the past 30 days) and ever-use of family planning. Women and men were asked about whether they or their partner had used or were currently using specific methods. A five-category family planning variable was created: had never used modern family planning and currently used no method, had practiced modern family planning in the past but was not currently using a method, currently used a reversible modern method (pill, injectable, condom, IUD or implant), currently used male or female sterilization for contraception; and currently used a traditional method. About half of the traditional method users had used mod-
TABLE 2. Percentage of women and men reporting selected decision-making attitudes and behaviors

\begin{tabular}{|c|c|c|}
\hline Attitude or behavior & Women & Men \\
\hline \multicolumn{3}{|l|}{ ATTITUDES ON DECISION MAKING } \\
\hline \multicolumn{3}{|l|}{ Men alone should decide } \\
\hline Family size & 17.8 & 18.8 \\
\hline Family planning $†$ & 14.9 & 17.4 \\
\hline \multicolumn{3}{|l|}{ Men alone should decide* } \\
\hline Family size or family planning (not both) & 16.7 & 20.5 \\
\hline Neither & 75.3 & 71.7 \\
\hline Both & 8.0 & 7.8 \\
\hline \multicolumn{3}{|l|}{ DECISION MAKING IN OWN HOUSEHOLD§ } \\
\hline \multicolumn{3}{|l|}{ Husband alone decides } \\
\hline Family size ${ }^{* * *}$ & 19.1 & 13.3 \\
\hline Family planning ${ }^{* * *}$ & 19.1 & 13.8 \\
\hline \multicolumn{3}{|l|}{ Husband alone decides*** } \\
\hline Family size or family planning (not both) & 16.6 & 15.1 \\
\hline Neither & 72.8 & 79.2 \\
\hline Both & 10.6 & 5.8 \\
\hline \multicolumn{3}{|l|}{ ATTITUDES VS. BEHAVIOR IN OWN HOUSEHOLD ${ }^{* * *},{ }^{*}+$} \\
\hline Men should make neither/husband makes neither & 61.0 & 65.9 \\
\hline Men should make neither/husband makes $\geq 1$ & 14.7 & 5.1 \\
\hline Men should make $\geq 1 /$ husband makes neither & 10.0 & 11.0 \\
\hline Men should make $\geq 1 /$ husband makes $\geq 1$ & 14.2 & 18.1 \\
\hline \multicolumn{3}{|c|}{$\begin{array}{l}{ }^{*} \mathrm{p} \leq .05 .{ }^{* *} \mathrm{p} \leq .01 .{ }^{* * *} \mathrm{p} \leq .001 .+\mathrm{p} \leq .10 \text {. } \neq \text { For females, } \mathrm{N}=7,158 \text {; for males, } \mathrm{N}=2,686 \\
\S \text { For family size decisions, } \mathrm{N}=6,981 \text { for females; } \mathrm{N}=2,553 \text { for males. For family } \\
\text { planning decisions, } \mathrm{N}=6,403 \text { for females; } \mathrm{N}=2,158 \text { for males. } \mathrm{t} \mathrm{N}=6,489 \text { for fe } \\
\text { males; } \mathrm{N}=2,223 \text { for males. Breslow-Day test of homogeneity of odds used to } \\
\text { determine significance. Notes: All values adjusted for weighting and clustered } \\
\text { survey design. Except in analyses of attitudes vs. behavior, adjusted Pearson-Walc } \\
\text { F-test used to determine significance. }\end{array}$} \\
\hline
\end{tabular}

ern methods in the past; these respondents were coded according to their current method use.

\section{Statistical Analysis}

We used bivariate analyses to examine differences between women and men in decision-making attitudes and in reported household decision making. We conducted multivariate logistic regression analyses to examine social and demographic factors associated with reporting at least one male-centered attitude (i.e., husbands alone should make family size or family planning decisions) and with reporting at least one male-centered behavior (husband alone made either decision in the respondent's household). The multivariate models included the respondent's age-group, place of residence, education level, religion, type of union and number of living children; the partner's education relative to the respondent's; and the household socioeconomic level. ${ }^{\ddagger}$

*For the multivariate analysis comparing women and men, we reweighted the men's sample to make its size more comparable to that of the women's sample, thereby making the ratio of men to women more similar to the ratio in the Honduran general population. This adjustment involved multiplying all men's weights by 2.4 . The result was an adjusted total weighted sample size of 11,973 men, compared with 11,990 respondents in the weighted sample of women.

tIn this article, "husbands" and "wives" include men and women who are in consensual unions as well as those who are married.

¥Socioeconomic status was classified as low, medium or high according to a goods-and-services index based on nine potential household features or possessions: piped water, toilet, electricity, radio, television, refrigerator, telephone, private vehicle, and electric or gas stove. 
TABLE 3. Adjusted odds ratios (and 95\% confidence intervals) from logistic regression analysis assessing associations between selected characteristics of Honduran women and men and believing that husbands alone should make decisions on family size or family planning use

\begin{tabular}{|c|c|c|}
\hline Characteristic & $\begin{array}{l}\text { Women } \\
(\mathrm{N}=7,159)\end{array}$ & $\begin{array}{l}\text { Men } \\
(\mathrm{N}=2,686)\end{array}$ \\
\hline \multicolumn{3}{|l|}{ Age-group (yrs.) } \\
\hline $15-24$ & $1.29(1.02-1.64)^{*}$ & $1.05(0.69-1.58)$ \\
\hline $25-29$ & $1.04(0.83-1.31)$ & $0.73(0.51-1.05)$ \\
\hline $30-34$ (ref) & 1.00 & 1.00 \\
\hline $35-39$ & $0.96(0.75-1.22)$ & $0.91(0.64-1.29)$ \\
\hline$\geq 40$ & $1.35(1.07-1.72)^{*}$ & $0.83(0.57-1.20)$ \\
\hline \multicolumn{3}{|l|}{ Residence } \\
\hline Tegucigalpa/San Pedro (ref) & 1.00 & 1.00 \\
\hline Other urban & $1.38(1.04-1.82)^{*}$ & $1.11(0.82-1.48)$ \\
\hline Rural & $1.51(1.15-2.00)^{* *}$ & $1.03(0.73-1.45)$ \\
\hline \multicolumn{3}{|l|}{ Educational level } \\
\hline None & $5.05(3.40-7.50)^{* * *}$ & $5.22(2.81-9.72)^{* * *}$ \\
\hline Primary & $3.22(2.36-4.41)^{* * *}$ & $2.58(1.69-3.92)^{* * *}$ \\
\hline$\geq$ secondary (ref) & 1.00 & 1.00 \\
\hline \multicolumn{3}{|l|}{ Socioeconomic level } \\
\hline Low & $2.34(1.73-3.17)^{* * *}$ & $1.24(0.78-1.96)$ \\
\hline Medium & $1.42(1.06-1.89)^{*}$ & $1.23(0.90-1.67)$ \\
\hline High (ref) & 1.00 & 1.00 \\
\hline \multicolumn{3}{|l|}{ Religion } \\
\hline Catholic (ref) & 1.00 & 1.00 \\
\hline Protestant & $1.23(1.04-1.46)^{*}$ & $1.17(0.86-1.60)$ \\
\hline Other/none & $1.15(0.94-1.41)$ & $1.09(0.79-1.49)$ \\
\hline \multicolumn{3}{|l|}{ Type of union } \\
\hline Marriage (ref) & 1.00 & 1.00 \\
\hline Consensual union & $1.26(1.07-1.49)^{* *}$ & $1.66(1.24-2.24)^{* * *}$ \\
\hline \multicolumn{3}{|l|}{ Partner's relative education } \\
\hline Lower & $1.15(0.93-1.42)$ & $1.52(1.07-2.14)^{*}$ \\
\hline Same (ref) & 1.00 & 1.00 \\
\hline Higher & $0.90(0.73-1.11)$ & $0.72(0.47-1.10)$ \\
\hline Don't know & $0.88(0.63-1.25)$ & $1.12(0.53-2.39)$ \\
\hline \multicolumn{3}{|l|}{ No. of living children } \\
\hline 0 (ref) & 1.00 & 1.00 \\
\hline $1-2$ & $0.66(0.50-0.88)^{* *}$ & $0.96(0.59-1.57)$ \\
\hline $3-4$ & $0.63(0.46-0.84)^{* *}$ & $0.89(0.54-1.48)$ \\
\hline$\geq 5$ & $0.60(0.44-0.83)^{* *}$ & $0.89(0.50-1.59)$ \\
\hline
\end{tabular}

For all analyses, we used STATA software, version 7SE, which controls for sample design and sampling weights. Our first two multivariable models (one for women and one for men) examined the social and demographic factors associated with a male-centered decision-making attitude. Similar analyses were performed to identify factors associated with male-centered household decision-making behavior. We also assessed the differences in male-centered decision making between the male and female samples in analyses with adjustment for covariates. The results of the joint men's and women's model are discussed in the text, but are not shown in the tables. (The full models are available from the first author on request.)

\section{RESULTS}

The male and female samples were similarly distributed across categories of residential location, socioeconomic level, type of union (marital vs. consensual) and contraceptive use
(Table 1, page 132). However, they differed in educational level, number of living children and religion. Moreover, the men generally were older than the women; persons as old as 50-59 years of age were eligible for the male sample, but not for the female sample. The age differential may explain women's higher educational level, because younger participants may have had increased access to education.

Eighteen percent of women and 19\% of men believed that husbands alone should make decisions about family size; $15 \%$ and $17 \%$, respectively, believed husbands alone should make family planning decisions (Table 2, page 133). For these two measures, women and men did not differ significantly, either in bivariate tests or in multivariate models that controlled for social and demographic characteristics (not shown).

Fifty-eight percent of women and $67 \%$ of men thought both partners should make decisions on family size, and $54 \%$ and $63 \%$ thought both partners should make decisions on family planning use (not shown). Overall, about a quarter of women (25\%) and men (28\%) reported a malecentered attitude on one or both of these measures; only $8 \%$ of women and $8 \%$ of men believed that husbands alone should make both types of decisions. The correlations between the two decision-making attitudes were moderate ( 0.40 for women, 0.33 for men).

The table also presents the percentage of women and men who reported that husbands alone made decisions on family size and family planning use in their household. For both measures, 19\% of women reported that their husband alone made the decisions. Thirteen percent of men reported making the decisions for their household on family size, and 14\% reported making the family planning decisions. For both of these measures, the proportions of men and women reporting male-centered decision making differed significantly. These differences remained significant in multivariate models that controlled for social and demographic characteristics (not shown).

Roughly half of women reported that both partners made family size decisions ( $57 \%$ ) or family planning decisions ( $52 \%$ ); for men, those proportions were $77 \%$ and $71 \%$, respectively (not shown). Although the percentages reporting male-centered household decision making were similar for the two measures, only $11 \%$ of women and $6 \%$ of men reported male-centered decision making for both. About a quarter of women (27\%) and men (21\%) reported at least one male-centered decision-making behavior in their household. The correlations between the two measures of behavior were 0.47 for women and 0.38 for menslightly higher than those for the two measures of attitude.

We also examined agreement between individual respondents' reports of decision-making attitudes and their reports of household decision-making behaviors. For this analysis, women and men were coded as having a male-centered attitude if they believed that husbands alone should make family size or family planning decisions, and they were coded as exhibiting a male-centered household decisionmaking behavior if they reported that in their household 


TABLE 4. Adjusted odds ratios (and 95\% confidence inter-
vals) from logistic regression analysis assessing associa-
tions between selected characteristics of Honduran women
and men and being in a partnership in which the man
makes the decisions on family size or family planning use

the husband alone made the decisions on family size or family planning. Sixty-one percent of women and $66 \%$ of men said that the man should not be the sole decision maker on either family size or family planning use, and that the male partner in their own relationship made neither type of decision on his own (Table 2). Fourteen percent of women and $18 \%$ of men reported that the husband alone should make at least one of these decisions, and that he did so in their household.

Fifteen percent of women said that men alone should not make the decisions on family size or family planning use, but that their own husband made at least one of those types of decisions. On the other hand, 10\% said that husbands should make one or both types of decisions, but that their own husband made neither. Among men, 5\% said husbands should not make either type of decision on their own, but reported that they themselves did so; $11 \%$ said husbands alone should make one or both types of decisions, but that they themselves made neither. According to a Breslow-Day test, men's responses on who should and who did make family size decisions (correlation of 0.56) and who should and who did make family planning decisions (correlation of 0.44 ) showed significantly greater agreement than did women's (correlations of 0.30 and 0.32 , respectively).

The first of two sets of multivariate logistic regression analyses was performed to identify selected social and demographic characteristics associated with male-centered decision-making attitudes (Table 3). Among women, those who had a primary school education or less, were Protestant, were of low or medium socioeconomic status, did not live in either of the country's two largest cities or were in a consensual union were more likely than other women to have such attitudes (odds ratios, 1.2-5.1). Other variables with significant findings for women were age and number of living children. Among men, those who had a primary school education or less, were in a consensual union or had a partner with less education than they themselves did were more likely than others to have a male-centered attitude (1.5-5.2).

The second set of multivariate analyses was conducted to identify variables associated with living in a household with male-centered reproductive decision making (Table 4). As in the analysis of factors related to male-centered attitudes, women who had a primary education or less, were of low or medium socioeconomic status or did not live in one of the country's two largest cities were more likely than other women to report that their husband alone decided on family size or family planning use (odds ratios, 1.3-3.1). However, age, union status and number of living children were not associated with the outcome variable.

For men, two of the variables associated with male-centered attitudes were also related to male-centered decisionmaking behavior: Having a primary education or less or being in a consensual union was associated with elevated odds of being the sole decision maker on family size or family planning use (odds ratios, 2.2-4.1). In addition, men of medium socioeconomic status had significantly higher odds of being the sole decision maker on at least one of these issues than did men of high status (1.7).

\section{Decision Making and Family Planning Use}

As Figure 1 (page 136) shows, the proportion of women who said that men alone should decide on family planning use was higher among those who had never used a modern method (23\%) and those who were currently relying on a traditional method (19\%) than it was among past or current users of modern methods (11-14\%). Likewise, the proportion of women who said that their husband alone made family planning decisions was significantly higher among those who had never used a modern method (25\%) and those who were currently using a traditional method (28\%) than it was among past and current users of modern methods (15-19\%). Among men, no significant differences were found between family planning use and reporting of male-centered family planning attitudes or household decision-making behaviors. 


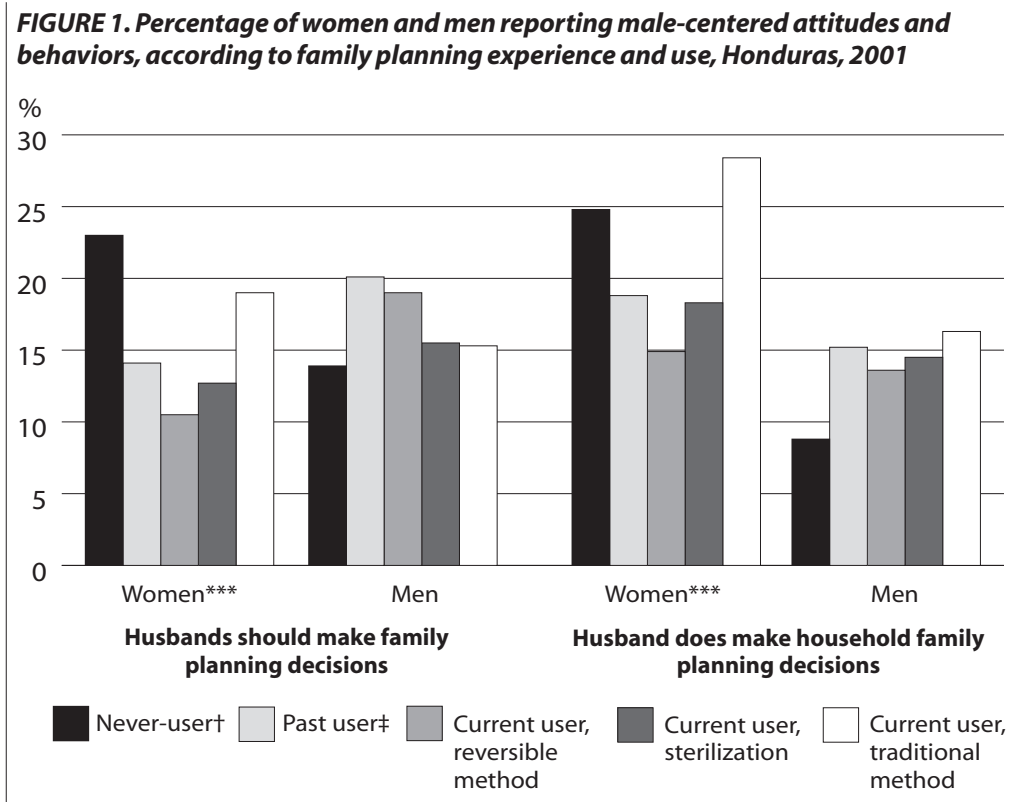

***Difference within gender between family planning experience and use groups significant at $\mathrm{p} \leq .001$. tRespondent who had never used a modern method and currently used no method. ‡Respondent who had used a modern method in the past but currently used no method.

\section{DISCUSSION}

In our sample, a quarter of women and men reported malecentered decision-making attitudes and behaviors related to family planning use or family size. The remaining respondents said either that decision making was shared or that it was handled exclusively by the woman. Although only $13-14 \%$ of male respondents said they had exclusive control of these decisions, women's reports suggest that that proportion was considerably larger. Once social and demographic characteristics were accounted for, women and men were equally likely to believe that men should make the decisions on one or both of these reproductive health issues. However, women were significantly more likely than men to report male-centered decision-making behavior in their household.

Individual respondents' opinions about who should make reproductive decisions were not always consistent with their reports about who actually did make these decisions in their household, and the patterns of inconsistency were different for women and men. For example, the proportion of respondents reporting that the man in their household made decisions he should not make was almost three times as high among women as among men. On the other hand, the proportions of men and women reporting that the man in their household did not make decisions he should be responsible for were roughly equal. Given that the data for men and women are not linked, it is difficult to determine whether men are making these decisions because they are playing a dominant role or because their wives are deferring to them or declining to participate in the decision-making process for some other reason.

This study identifies factors that may affect equity in reproductive decision making. According to our findings, women who lived in less urban areas, had less than a sec- ondary education or were of medium or low socioeconomic status had elevated odds both of believing that men alone should make reproductive decisions and of living in a household in which the man made those decisions.

One possible explanation for the importance of these factors is that women who live in more urban areas-who tend to be more educated and of a higher socioeconomic status $^{14}$-have increased access to family planning information and services. In Honduras, most women have access to family planning services at a health post, a health clinic or a hospital. Although women in rural areas often have ready access only to health posts-the lowest tier of service-the care provided at these facilities is free. They must still pay, however, for the cost of getting to the facility, staying at the facility or spending long periods waiting for services. Whether these service barriers affect rural women's attitudes on who should make reproductive decisions or the reality of who makes those decisions in their household is unclear. These women may have traditional lifestyles in which men usually still make the decisions. As levels of education rise among rural women, their decision-making attitudes and behaviors may change.

Among men, education appears to be the most important factor. The least educated men had elevated odds of supporting and practicing male-centered decision making.

The multivariate analyses revealed that women's odds of supporting male-centered decision making decreased as their number of children rose. Although having more children is generally associated with older age, women aged 40-49 were more likely than women in their early 30 s to have male-centered decision-making attitudes. This may indicate generational differences that affect women's attitudes, such that the oldest women in the sample had attitudes more conservative than women in the younger agegroups. This finding could also indicate a change in women's relative power over the life course: From this perspective, women with no children would be the most likely to have male-centered decision-making attitudes, but as they have more children, and thus gain more control over household resources, their attitudes may change. These attitudinal patterns could also reflect women's growing ability and desire to control their procreative lives as they have more children and gain greater exposure and access to reproductive health services. However, neither age nor parity was associated with who actually made reproductive decisions in women's households. Thus, generational and life-course differences appear to be affecting decision-making attitudes, but not household decision making.

Among women, being in a consensual union was associated with male-centered decision-making attitudes. However, type of union was not associated with decision-making behavior. Other research has found that women in consensual unions often have less bargaining power than married women vis-à-vis their spouses. ${ }^{15}$ Perhaps women in consensual unions tend to perceive themselves as having less influence over reproductive decision making than they actually do. 
For men, those in consensual unions support and practice male-centered decision making. Whether men realize that this type of union might strengthen their decision-making power on reproductive matters is unknown. Future studies that obtain more contextual information on relationship dynamics among women in consensual unions (i.e., whether the partners are divorced and unable to remarry in the church, whether consensual unions are associated with high rates of poverty, and whether women's greater economic independence perhaps influences them to choose a less legally restrictive relationship) would help to explain how consensual unions affect decision-making attitudes and behaviors. Studies should obtain in-depth information on relationship status and the role of union type on relationship dynamics. For example, an investigation of women's views on whether their partner has other sexual partners could provide insight on whether consensual unions are associated with women's lack of influence in decision making because their fear of partner abandonment is greater than that of married women. In addition, obtaining information from men and women in consensual unions on whether they intend to formalize their status might reveal different levels of commitment within consensual unions. Finally, future surveys should include additional measures of the type of decisions that require both partners' input and of why one gender might dominate in certain types of decisions.

In our study, family planning method use was associated with decision-making attitudes and behaviors among women but not among men. This link might reflect women's increased ability to affect their reproductive health decisions as they experience motherhood and become exposed to reproductive health services. Moreover, given that the most educated women and urban women are most likely to practice contraception, this pattern might reflect demographic factors associated with who makes reproductive decisions.

\section{Limitations}

Although numerous societal and individual circumstances are thought to influence gender-related norms and behavior, the data used in this study limited our examination to gender and indicators of social class, education and residential area. A clearer understanding of power and bargaining processes in sexual relationships requires an examination of partners' influence relative to one another regarding decision making on intrahousehold and extrahousehold matters and should take into account how the broader political, social and economic contexts shape partners' decision-making power. ${ }^{16}$

The 2001 surveys used single measures to assess respondents' decision-making attitudes and behavior regarding family size and family planning. These survey items could not fully capture the complex dynamics behind such processes. Moreover, with these data, we could not examine couples' decision making as reported by spouses. Decision making regarding reproductive matters rarely involves only one person (although in the end, one partner's wishes may prevail). Future studies should include additional information obtained from couples to enhance our understanding of relationship dynamics regarding perceptions and actual behaviors. Finally, we could not establish causal relationships between associated variables because of the surveys' cross-sectional design.

\section{Conclusion}

Both the proportion of men who reported believing that husbands alone should make family size decisions and the proportion reporting that husbands alone should make family planning decisions decreased between 1996 and 2001. ${ }^{17}$ Although more than half of men and women in the 2001 surveys supported shared decision making, our analysis indicates that some women in Honduras have less control over their fertility than they want. Indeed, the 2001 Honduran survey data reveal that a higher proportion of women than men reported having more children than they had wanted. ${ }^{18}$

Our results provide important information about reproductive decision making in Honduras for subsequent development of programs targeting men's participation. The results underscore the need for public health efforts that recognize power imbalances and promote gender equity, especially among those categories of women and men who are the most likely to report male-centered perspectives (rural residents, persons in consensual unions and those with relatively little education). Telling women to talk with their husbands about reproductive decision making would probably be unhelpful in places where prevailing gender norms do not encourage this type of communication. Thus, programs need to target men directly with strategies that encourage them to communicate with their wives about reproductive decisions. These strategies could include using community outreach workers in factories or other locations where men congregate in rural areas; mass media campaigns that show a group of men discussing the usefulness of having discussed reproductive decisions with their wives; and working in schools to encourage more balanced relationship dynamics between males and females from an early age. These types of efforts would improve women's and men's abilities to meet their childbearing goals and, in combination with other social forces in Honduras, contribute to broader health improvements associated with gender equity.

\section{REFERENCES}

1. Population Council and Interagency Gender Working Group (IGWG), Power in sexual relationships: an opening dialogue among reproductive health professionals, New York: Population Council, 2001.

2. Speizer IS, Are husbands a barrier to women's family planning use? the case of Morocco, Social Biology, 1999, 46(1-2):1-16; Bankole A and Singh S, Couples' fertility and contraceptive decision-making in developing countries: hearing the man's voice, International Family Planning Perspectives, 1998, 24(1):15-24; and Becker S, Measuring unmet need: wives, husbands or couples? International Family Planning Perspectives, 1999, 25(4):172-180

3. Watkins S, Rutenberg N and Wilkinson D, Orderly theories, disorderly women, in: Jones GW et al., The Continuing Demographic Transition, 
New York: Oxford University Press, 1997; and Bawah AA et al., Women's fears and men's anxieties: the impact of family planning on gender relations in northern Ghana, Studies in Family Planning, 1999, 30(1):54-66.

4. Blanc A, The effects of power in sexual relationships on sexual and reproductive health: an examination of the evidence, Studies in Family Planning, 2001, 32(3):189-213.

5. Speizer IS, 1999, op. cit. (see reference 2).

6. Population Council and IGWG, 2001, op. cit. (see reference 1)

7. Kishor S, Autonomy and Egyptian Women: Findings from the 1988 Egypt Demographic and Health Survey, DHS Occasional Papers, Calverton, MD USA: Macro International, 1995, No. 2; Kishor S, Women's contraceptive use in Egypt: what do direct measures of empowerment tell us? Paper presented at the annual meeting of the Population Association of America, Los Angeles, CA, USA, Mar. 23-25, 2000; Kritz M, MakinwaAdebusoye P and Gurak D, The role of gender context in shaping reproductive behavior in Nigeria, in: Presser HB and Sen G, eds., Women's Empowerment and Demographic Processes: Moving Beyond Cairo, Oxford, UK: Oxford University Press, 2000; and Mason K and Smith H, Husbands' versus wives' fertility goals and use of contraception: the influence of gender context in five Asian countries, Demography, 2000 37(3):299-311

8. Vigoya MV, Contemporary Latin American perspectives on masculinity, Men and Masculinities, 2001, 3(3):237-260.

9. Hirsch JA, Courtship After Marriage: Sexuality and Love in Mexican Transnational Families, Berkeley, CA, USA: University of California Press, 2003.

10. World Bank, Challenges and opportunities for gender equity in Latin America and the Caribbean, 2003, <http://wbln0018.worldbank.org/ LAC/LAC.nsf/0/98CClA5B56B2733985256CDF006DF094?Opendoc ument>, accessed Sept. 16, 2005; and Brea JA, Population dynamics in Latin America, Population Bulletin, 2003, 58(1):3-36

11. Ministry of Health, Honduras, and Honduras Family Planning Association, Honduras: Encuesta Nacional de Epidemiología y Salud Familiar-2001, y Encuesta Nacional de Salud Masculina, Informe Final, Atlanta, GA, USA: Centers for Disease Control and Prevention (CDC), 2002.

12. Ibid.

13. Ibid

14. World Bank, 2003, op. cit. (see reference 10)

15. Parrado E and Tienda M, Women's roles and family formation in Venezuela: new forms of consensual union? Social Biology, 1997, 44(1): 1-24; and Desai S, Children at risk: the role of family structure in Latin America and West Africa, Population and Development Review, 1992 18(4):689-717.

16. Blanc A, 2001, op. cit. (see reference 4); and Argawal B, "Bargaining" and gender relations: within and beyond the household, Feminist Economics, 1997, 3(1):1-51.

17. Ministry of Health, Honduras, and Honduras Family Planning Association, 2002, op. cit. (see reference 11); and Ministry of Health, Honduras, and Honduras Family Planning Association, Honduras: Encuesta Nacional de Salud Masculina-1996, Informe Final, Atlanta, GA USA: CDC, 1998

18. Ministry of Health, Honduras, and Honduras Family Planning Association, 2002, op. cit. (see reference 11).

\section{RESUMEN}

Contexto: Las diferencias de género influyen en la toma de decisiones en materia de salud reproductiva. La mayor parte de la información disponible de América Latina sobre el proceso de la toma de estas decisiones proviene de datos suministrados por las mujeres sobre la participación de los hombres.

Métodos: Los datos fueron recopilados en Honduras, en 2001, mediante dos encuestas nacionales que utilizaron muestras independientes de hombres de 15-59 años y de mujeres de 15-49 años. Se utilizaron análisis bivariados y multivariados para identificar los factores relacionados con la actitud y práctica de que el hombre domina la toma de decisiones con respecto al número de hijos y el uso de servicios de planificación familiar.

Resultados: En general, el 25\% de las mujeres y el 28\% de los hombres indicaron que el hombre debería ser responsable por sí solo de una mínima de una de estas decisiones (tamaño de la familia y uso de anticonceptivos), y el 27\% de las mujeres y el $21 \%$ de los hombres indicaron que una o ambas de estas decisiones eran tomadas, en verdad, por el hombre en su hogar. Entre las mujeres, los factores de no tener hijos y vivir en una unión consensual estuvieron relacionados con tener una actitud de que el hombre es el que toma la decisión en la pareja. Cuando examinamos los factores que incidian en la toma de decisiones por parte del hombre, los factores significativos entre las mujeres eran haber cursado estudios inferiores a enseñanza secundaria, poseer una condición socioeconómica media o baja, y residir en una zona rural. Entre los hombres, haber obtenido menos de un nivel de enseñanza secundaria y vivir en una unión consensual estuvieron relacionados con ambos resultados examinados, las actitudes y las conductas acerca de la dominación del hombre en tales decisiones. Las mujeres que habian usado alguna vez o estaban actualmente utilizando métodos anticonceptivos modernos fueron significativamente menos proclives que las mujeres que usaban métodos tradicionales o que nunca habían usado un método moderno a mantener las actitudes que apoyaban la participación predominante del hombre en la toma de decisiones sobre la reproducción.

Conclusiones: Los programas deben reconocer los desequilibrios que existen en cuestiones de poder entre los géneros, los cuales afectan la capacidad de la mujer de lograr sus metas de fecundidad deseada. En las zonas rurales, los programas deben concentrar la atención en los hombres, alentándolos a comunicarse con sus parejas y a adoptar en forma conjunta las decisiones sobre cuestiones reproductivas.

\section{RÉSUMÉ}

Contexte: Les différences sexospécifiques influencent les décisions de santé reproductive. L'information sur ces décisions en Amérique latine provient principalement des déclarations féminines de participation des hommes.

Méthodes: Les données ont été recueillies au Honduras, en 2001, à travers deux enquêtes nationales menées auprès d'échantillons indépendants d'hommes de 15 à 59 ans et de femmes de 15 à 49 ans. L'analyse bivariée et multivariée a permis d'identifier les facteurs associés aux attitudes et comportements décisionnels centrés sur l'homme en ce qui concerne le nombre d'enfants et le recours au planning familial.

Résultats: Dans l'ensemble, 25\% des femmes et 28\% des hommes ont indiqué que les hommes seuls devraient assumer au moins une de ces décisions reproductives, tandis que 27\% des femmes et $21 \%$ des hommes déclaraient que l'homme du ménage arrêtait une de ces décisions ou les deux. Côtéfemmes, l'absence d'enfants et l'union consensuelle étaient toutes deux associées à des attitudes de décision centrées sur l'homme; l'instruction inférieure au niveau secondaire, le niveau socioéconomique moyen ou faible et la résidence en milieu rural étaient tous trois associés à un processus décisionnel centré sur l'homme. 
Côté hommes, l'instruction inférieure au niveau secondaire et l'union consensuelle étaient toutes deux associées à des attitudes et à un comportement décisionnels centrés sur l'homme. Les femmes qui avaient jamais pratiqué ou qui pratiquaient les méthodes modernes se sont avérées significativement moins susceptibles de soutenir la décision centrée sur l'homme que celles qui recouraient aux méthodes traditionnelles ou qui n'avaient jamais utilisé de méthode moderne.

Conclusions: Les programmes devraient reconnaître les déséquilibres sexospécifiques qui affectent la capacité des femmes de satisfaire leurs désirs de fécondité déclarés. Dans les régions rurales, les programmes devraient cibler les hommes et les encourager à communiquer avec leur épouse sur la question des décisions en matière de reproduction.

\section{Acknowledgments}

The authors thank Richard Monteith, Brenda Colley Gilbert, Paul Stupp, Donna McClish and Chris Johnson for their helpful insights.

Author contact: ilene_speizer@unc.edu 